\title{
The Perishable Press Limited
}

The privately owned and operated Perishable Press Limited, now in its fourteenth year, was established by Walter S. Hamady, associate professor of art at the University of Wisconsin-Madison, and is run by Walter and Mary Hamady in their own home on a farm in Mount Horeb, Wisconsin. Except for some hand-binding by Elizabeth Kner in Chicago, Douglas and Sandy Cockerell in England, and one or two others, all the work is done by the Hamadys, with occasional help or personal touches by friends, such as marbled end papers or a personalized pressmark from Beirut. Walter Hamady says that the press is "essentially a glorified hobby." All the printing is done on a Vandercook SP15 without power inking, and work is done in the house except for papermaking, which formerly was done in the basement and since February of 1978 in the remodelled bottom floor of the barn. The paper they have made since 1969 is named Shadwell, after Thomas Jefferson's birthplace. It has a heavy, rough texture and is produced in a variety of subtle shades of color.

Type is set by hand, and the printer has managed to get the Thompson Type Caster working in the barn; he is excited by the prospect of the possibilities it will afford the press. Next he hopes to have a pangraphic engraving machine which will enable them to make their own mats.

In 1969 Mr. Hamady received a Guggenheim fellowship to study hand-papermaking abroad. His most recent work has been assisted by the Howard Foundation, the National Endowment for the Arts, and the Wisconsin Alumni Research Foundation. For excellence in design and printing he received the American Institute of Graphic Arts' Fifty Best Books Award for Spider Poems by Walter Hall in 1967 and for Loren Eiseley's The Brown Wasps in 1969. His Guillem de Poitou, translated by Paul Blackburn, and Chapter Seven from The Hour of the Bell by Harry Mark Petrakis were included in the 1976 A.I.G.A.'s Best Books Show. The press has had books represented also at the 
Madison Art Center, Madison, Wisconsin, the Print Club of Philadelphia, and at the Grolier Club in New York City.

Walter Hamady is not only a printer and papermaker but a poet and artist (as is his wife, Mary), whose own poems have appeared in New Directions, and whose literary interests are reflected in the outstanding contemporary authors, almost entirely poets, whose work he has printed in limited, signed editions. Besides the work of W. S. Merwin, Howard Nemerov, Robert Creeley, J. V. Cunningham, Paul Blackburn, William Stafford, W. D. Snodgrass, Denise Levertov, and other literary figures, the poetry and drawings of both Walter and Mary Hamady are represented.

In his desire for unique artistic expression, Walter Hamady has turned out some very unusual-looking books, such as his own Book No. 68, Pulsars by Harry Lewis, or A Poem to Celebrate the Spring and Diane Rothenberg's Birthday by Jerome Rothenberg, to name only a few, in which he may combine a variety of sizes and colors of page, type, ink, and various paper textures, with intent toward serious design or humorous effects. This sense of humor, of puns and jokes, is most noticeable in the elaborate colophons which describe the materials used, the date of completion, or other informative comments, pertinent or impertinent, that the printer wishes to make. Quotations from certain of the colophons have been included in the following checklist because of their personal flavor and also because they may enable the reader of the checklist to visualize each book as much as is possible without having it in hand.

Previous discussions of the Perishable Press Limited have appeared in the Missouri Library Association Quarterly (September 1969), edited by John Gordon Burke; in Gretchen Lagana's "An Interview with Walter Hamady," U. W. Library News (March 1972); in American Libraries (April 1973); and in a review by Stephen Harvard in Fine Print (October 1977), where Hamady's books are praised for "excellent printing and innovative typography" and also "as the authoritative work of a fine and generous spirit. It is the last attribute, a whole greater than the sum of its parts, that separates Perishable Press books from the herd of private imprints." In The Printed Book in America (1977), Joseph Blumenthal remarks, apropos of Hamady's work, that "his craftsmanship is nothing short of brilliant, especially in the sometimes witty and playful ephemera."1

1 Additional, usually briefer, comments on the Press appear in Bibliography Newsletter (July-August 1976):13-14 and (December 1977):11; Roderick Cave's The Prtuate Press (London 1971), p. 270; Book Publishing in Wisconsin, edited by Danky et al. (August 1977), pp. 76-77; and annual issues of Private Press Books as well as issues of A.I.G.A. Fifty Books exhibit catalogs for 1967, 1968, and 1976. 
The checklist which follows is limited to books, pamphlets, and broadsides. Present holdings of The University of Iowa Libraries are indicated by the symbol "IaU" following relevant items. An asterisk following an entry indicates that the item was examined by the compiler at first hand in the Memorial Library's collection at the University of Wisconsin. ${ }^{2}$

It seems appropriate to conclude this introduction with the Hamadys' own statement of their purpose:

The Perishable Press Limited was established in 1964 and was so named because it seemed to most adequately describe the human condition, which is both perishable and limited. The purposes of private printing are several. Aside from the therapeutic aspect (which may be the most important), the two most essential ones are, simply, that the press make a contribution in the content of the work it produces, and that a relationship be made between the heritage of fine printing and the graphic discoveries of the current century.

\section{4}

1. THE DISILLUSIONED SOLIPSIST and nine related poems, by Walter S. Hamady, illustrated with two original etchings by the poet, and a colored photograph. 14 pp.; 23 x $19 \mathrm{~cm}$; Caslon Old Style; 60 copies on cheap offset paper; bound in wrappers by the author.

\section{5}

2. EPHEMERAL GENESIS \& PARADISE, by Walter S. Hamady, some of the 16 poems illustrated. 20 pp.; $28 \times 22 \mathrm{~cm}$; Caslon Old Style, DeVinne, Cloister, and Garamond type; 25 copies on the first papers

A priced sale offering of over 50 items printed at the Perishable Press Limited appears in Catalogue 20, "American Fine Printing," of W. Thomas Taylor, Bookseller, Austin, Texas (circa April 1977). Fifteen of the Press publications are offered in Catalogue 192, "The Printer and the Artist," of Bertram Rota Ltd., London (circa February 1975). In addition to his own Notes Regarding Papermaking by $H$ and (item $8 f$ in the accompanying checklist), Walter Hamady presently has in preparation a book on Hand Making of Paper.

2 I should like to thank Edwin Hill of the Murphy Library, University of Wisconsin at LaCrosse; Evert Volkersz of the Library at SUNY at Stony Brook; and Frank Paluka, The University of Iowa Libraries, for supplying copies of cards for their Perishable Press holdings. Gretchen Lagana and her staff at the Rare Books Department of the Memorial Library, University of Wisconsin, Madison, supplied information and allowed me to examine all the items in their Perishable Press collection. Professor Jack Clarke of the University of Wisconsin Library School, Madison, and Louise Henning of the Kohler Art Library, Madison, were helpful sources of information. Thanks are also due to Walter S. Hamady, who has reviewed this checklist and supplied necessary information. 
made by the author; unsewn, in folded Fabriano wrapper, in a slipcase by Elizabeth Kner.

3. WORDS, by Robert Creeley. [15] pp. on double leaves; $23 \times 19 \mathrm{~cm}$; Caslon Old Style; 30 copies on paper by the printer, signed by the author; bound in Fabriano over boards by Elizabeth Kner.

4. SIX POEMS \& PICTURES, a collaboration of six poems by Walter S. Hamady and six pictures by Aris Koutroulis. [18] pp. on double leaves; $23 \mathrm{~cm}$; display in SB Caslon Old Face, text reproduced from author's handwriting; 30 copies: 22 on white handmade paper, 5 on grey oatmeal, 1 on blue, 1 on grey-blue, and 1 on light brown, all printed by hand-lithography; handmade papers over boards, with vellum tips and spine done by Peter Franck.

THE DREAME, by John Donne. Broadside; $43 \times 35 \mathrm{~cm}$; Caslon Old Style; 25 copies on the printer's handmade paper. Ia $U$.

ELEGIE: CHANGE, by John Donne. Broadside; $43 \times 35 \mathrm{~cm}$; Caslon Old Style; 75 copies printed by WSH at Robert E. Runser's Rob Run Press, on the printer's handmade paper.

ELEGIE: GOING TO BED, by John Donne. Broadside; 44 x $35 \mathrm{~cm}$; Caslon Old Style; 75 copies printed by WSH at Robert E. Runser's Rob Run Press on the printer's handmade paper. Ia $U$.

LATIN LINES, by J. V. Cunningham. Broadside; $26 \times 21 \mathrm{~cm}$; Caslon Old Style; 75 copies on Shadwell.

THE QUARRY, by Howard Nemerov. Broadside; 26 x $21 \mathrm{~cm}$; ATF Caslon 471 ; 100 copies on Shadwell. (This was never issued; only known copy at SUNY.)

STORM WINDOWS, by Howard Nemerov. Broadside; $26 \times 21 \mathrm{~cm}$; Caslon Old Style; 77 copies on Shadwell.

5. CONSENTING SHADOWS, a collaboration of poems and pictures by Aris Koutroulis and Walter Hamady ("Eight poems \& half of five pictures by WH and the other half by AK. The pictures are color lithographs integrated with the text"). 20 pp.; $24 \mathrm{~cm}$; Goudy Old Style; 18 copies on papers made by the author.

6. SIX PROSE PIECES, by Robert Duncan, with one illustration, an end-wood-cut by Walter Hamady, after a drawing by the author; 16 pp. on double leaves; $23 \mathrm{~cm}$; Goudy Old Style; 70 copies on the printer's handmade paper; cloth over boards, with gold stamping of 
the author's signature on the cover; 15 signed, unsewn copies in a slipcase by Elizabeth Kner.

7. CLOSING FLOWERS [nineteen short poems], by Walter Hamady. 25 pp.; 23 x $19 \mathrm{~cm}$; Goudy Old Style; 30 copies "on variegated papers hand-made by the printer and pulled on the Washington at Robert Runser's"; 13 copies bound in cloth over boards by Elizabeth Kner."

8. THE PLUMFOOT POEMS I, by Walter Hamady, illustrated by the author. 25 pp.; $22 \times 19 \mathrm{~cm}$; Palatino and Michaelangelo; 7 copies on Shadwell handmade paper; bound by Elizabeth Kner.

AFTER BIRTH, by Bernard Waldrop. Broadside; 45 x $36 \mathrm{~cm}$; Goudy Old Style; 70 copies on Shadwell. Ia $U$.

DANGERS OF REASONING BY ANALOGY, by Howard Nemerov. Broadside; 28 x $21 \mathrm{~cm}$; Goudy; 80 copies on Shadwell.

FOR JOEL, by Robert Creeley. Broadside; 28 x $21 \mathrm{~cm}$; Goudy; 85 copies "on variegated paper hand-made directly from rags." ("For Joel and Helen Oppenheimer on the occasion of their marriage, 6 June 1966.")

HALLOWEEN POEM by Susan Hamady. Broadside; $23 \%$ x $20 \% \mathrm{~cm}$; Stemple Palatino; "a few copies" on Shadwell "as a Thanksgiving surprise."

LOUIS COMFORT TIFFANY: PROPOSAL FOR FELLOWSHIP, by Walter Hamady. Broadside; $36 \times 22 \mathrm{~cm}$; Goudy Old Style; 10 copies printed at the Rob Run Press.

NOTES REGARDING PAPERMAKING BY HAND, by W. Hamady. Broadside; $47 \times 37 \mathrm{~cm}$; Centaur and Arrighi; 16 copies on handmade paper. Reprinted from the winter issue of Among Friends, a quarterly of the Detroit Public Library.

PSALM CONCERNING THE CASTLE, by Denise Levertov. Broadside; 36 x $27 \mathrm{~cm}$; Goudy Old Style; 70 copies on handmade paper. ${ }^{\circ}$

RINGWALT'S ENCYCLOPAEDIA, by Robert E. Runser. Broadside; 45 x 31 cm; Goudy Old Style; may be 5 copies on newsprint and bond.

TIGHT THIGHS, by Walter Hamady, illustrated by the author. Broadside; 26 × 20\% cm; SB Caslon Old Style; 20 copies on Shadwell.

\section{7}

9. THE REARDON POEMS, by Paul Blackburn. 10 leaves; $25 \mathrm{~cm}$; Palatino and Michaelangelo from Stempel; red and black; 143 copies: 100 in one signature, bound in soft cover, and 40 in three signatures, hardbound, all on handmade Chauke Heavy from Japan; 3 in 12 sig- 
natures on Shadwell handmade paper, hardbound by Elizabeth Kner. Ia $U$.

10. SPIDER POEMS, by Walter Hall. [5] + 11 leaves; $25 \mathrm{~cm}$; Palatino; 250 copies on mould-made Nideggen paper; hand bound in blindstamped cloth over boards by Elizabeth Kner. "50 copies special, in little ways, signed by the author." The author's first book. Ia U."

11. SIRVENTES ON A SAD OCCURRENCE, by Joel Oppenheimer. [3] $+6+[1]$ leaves; $19 \mathrm{~cm}$; Palatino; 130 copies on Arches text and Nideggen papers; wrappers. $I a U .^{\circ}$

12. PLUMFOOT POEMS, by Walter Hamady, illustrated by the author. [3] + 21 + [1] pp.: $20 \mathrm{~cm}$; Palatino: 200 copies on Medway; halfleather and cloth over boards by Elizabeth Kner. Ia U."

13. SOME SALT, poems and epigrams, titled Aliquid Salis ..., by J. V. Cunningham. [3] $+14+[1]$ leaves. $20 \times 13^{\frac{1}{2}} \mathrm{~cm}$; Palatino; 200 copies on Crown \& Sceptre, a J. Barcham Green paper handmade in England; hand-sewn Fabriano wrapper. $I a U .^{\circ}$

14. THE CHARM; early and uncollected poems, by Robert Creeley. 77 folded leaves; $22 \mathrm{~cm}$; Palatino; 250 copies on Medway paper, numbered and signed by the author; leather and cloth over boards by Elizabeth Kner. Ia $U$. $^{\circ}$

IT MIGHT AS WELL BE SPRING, by Paul Blackburn. Broadside; $30 \times 20$ cm; Palatino; 100 copies: half on Medway and half on papers made by the Press.

PROSPECTUS NUMBER TWO, by Walter Hamady. Broadside printed on both sides, $33 \times 13 \% \mathrm{~cm}$; Palatino.

RETRO-PROS-PECTUS 1965 :: 1967, by Walter Hamady. Broadside; $32 \times$ $31 \mathrm{~cm}$; Palatino.*

\section{8}

15. DIVISIONS \& OTHER EARLY POEMS, by Robert Creeley. 19 pp.; $22 \mathrm{~cm}$; Palatino; 110 copies on Shadwell: 100 numbered 1 through 100 and 10 for the author numbered I through $\mathrm{X}$; hand-sewn wrapper of Fabriano Cover. Ia U."

16. ELEVEN UNTITLED POEMS, by William Stafford. [28] pp.; $21 \mathrm{x}$ $15 \mathrm{~cm}$; Palatino; 250 numbered copies: 50 on Shadwell and 200 on Medway, a Barcham Green handmade paper; hand-sewn wrapper of Fabriano with a silk-screened diagram of a geological formation, illustrated by Walter Hamady. Ia U. 
17. LIGHT FROM UNDER A BUSHEL, by Mitchell Goodman. 15 leaves; $24 \mathrm{~cm}$; Palatino; 100 copies on Highclere, a J. Barcham Green handmade paper, hors commerce "for the author and his friends to remember Christmas 1967"; handsewn Fabriano wrapper.

18. TWO NEW POEMS, by Paul Blackburn, illustrated by Walter Hamady. 5 leaves; $14 \times 20 \mathrm{~cm}$; Palatino and Michaelangelo; 10 copies on Shadwell "evenly divided between poet and printer and not for sale." Ia $U$.

19. UNHIRED, by John Wieners. 7 pp.; $20 \mathrm{~cm}$; Palatino; 250 copies on variegated Shadwell handmade paper; blue wrappers. Ia. $U .^{*}$

20. THREE POEMS, by Denise Levertov, illustrated by Walter Hamady. 6 leaves; $22 \mathrm{~cm}$; Palatino; 250 copies on grey Shadwell. Ia $U$.

BOOKS, Th Prshbl Prss Imtd, by Walter Hamady, 4 leaves; $22 \times 15 \mathrm{~cm}$; Palatino and Michaelangelo; 100 copies, approximately, on Medway; Fabriano wrappers."

21. ALPINE, by George Oppen, with a blind-stamped illustration on the dedication page by "an anonymous German geologist" [W.S.H.] [2 + 9] pp.; $25 \mathrm{~cm}$; Palatino; 250 copies on Shadwell; tan wrappers. Ia U. ${ }^{\circ}$

22. THE BROWN WASPS: a collection of three essays in autobiography, by Loren Eiseley, illustrated with a frontispiece drawing by Jack Beal. [4 1.] $+29+$ [1] pp.; $22 \mathrm{~cm}$; Palatino; 256 copies: 200 on handmade Charter Oak; 56 on Shadwell; marbled paper over boards. Ia $U .^{\circ}$

23. THE DRIVERS, by Carl Thayler, illustrated by Jack Damer. [19] pp.; $22 \times 14 \mathrm{~cm}$; Palatino; 220 copies on Shadwell; wrappers.

24. THANKING MY MOTHER FOR PIANO LESSONS, by Diane Wakoski. [15] pp.; $14 \times 20 \mathrm{~cm}$; Palatino and Saphir; 250 copies on Shadwell; wrappers. Ia $U .^{\circ}$

25. WEATHER, poems, by William Stafford, with an illustrated title page by Jack Beal. [22] pp;; $22 \mathrm{~cm}$; Palatino and Smaragd; 207 copies on Shadwell; handsewn into Fabriano wrappers. I $\mathrm{U}$."

26. SINCE MARY, seventeen new poems, by Walter S. Hamady. [23] pp.; $14 \times 14 \mathrm{~cm}$; Palatino and Smaragd in red, black, and brown; 167 copies on handmade paper; wrappers. There are variant printings of the title page." 
27. MAPS, poems, by Toby Olson, title page with a blind-stamped design by Walter Hamady. [23] pp.; $28 \mathrm{~cm}$; Palatino and Smaragd (from Stempel); 132 copies on Shadwell; handbound by Douglas Cockerell \& Son. ("There are four copies bound a little more special [for] author, binder, apprentice vatman, and publisher.") I $a U .{ }^{\circ}$

28. WORMS INTO NAILS, poems, by Toby Olson, illustrated with a drawing by Jack Beal. [2 +29 ] pp.; $25 \mathrm{~cm}$; Palatino; 200 copies on Fabriano Book paper, signed by the author and hand numbered; dark blue cloth over boards by Moroquain, with the Jack Beal drawing gold-stamped on the front cover. Ia $U .^{\circ}$

29. THE BRAND, a five-part poem, by Toby Olson. [15] pp.; $20 \mathrm{~cm}$; Palatino; 140 copies on handmade paper, of which 77 are for sale; hand sewn into Fabriano wrappers, with dust-jacket illustration by Walter Hamady."

30. THIS GENTLE STRENGTH WE SHARE, poems and engravings, by Mary Hamady. [25] pp.; $22 \mathrm{~cm}$; Palatino; 30 copies on Shadwell; paper wrappers. ("Quelquefois Press.")

31. THE ASSASSINATION OF PRESIDENT McKINLEY, a poem, by Paul Blackburn, illustrated by Warrington Colescott. [7] pp.; $21 \mathrm{~cm}$; Palatino; 125 copies or less, all hors commerce, for the friends of poet, artist and printer; on Shadwell made from the author's clothes; wrappers. Ia $U$.

32. THE PIG, poems, by James Laughlin. [26] pp.; $22 \mathrm{~cm}$; Palatino and Smaragd; 183 copies on Shadwell handmade paper, of which 48 copies are beige and 135 are white; binding by Elizabeth Kner. I $a$ U."

33. TWO POEMS, by Michael Heller. [8] leaves; $21 \mathrm{~cm}$; Palatino, printed in black with red and beige-grey inks; 142 copies on grey Shadwell paper; handsewn in grey Fabriano wrappers. (SUNY notes a variant printing.) Ia $U .^{\circ}$

34. SONGS FROM THE DECLINE OF THE WEST, by Keith Waldrop, illustrated with a drawing by Warrington Colescott. [15] leaves; 29 x $191 / 2 \mathrm{~cm}$; Palatino and Smaragd in black and red; 120 numbered copies on Shadwell paper: 3 copies on grey, 12 copies on chocolate, and 105 copies on special-made "real light banana"; cloth with leather spine."

35. GIN, four journal pieces, by Paul Blackburn. [10] leaves, counting bastard title; $29 \mathrm{~cm}$; Palatino and Smaragd in black, red, and tan; 136 copies "on the first ream of Shadwell made in our new house south of 
Blue Mounds"; hand binding in marbled paper boards and vellum by Douglas Cockerell and Son. Ia $U$.

36. REMAINS, poems, by S. S. Gardons [i.e., W. D. Snodgrass], with title-page illustration by Walter S. Hamady. [25] pp.; $21 \%$ x $14 \% \mathrm{~cm}$; Palatino; 200 press-numbered copies on Shadwell handmade paper; half-leather and marbled paper by Douglas Cockerell and Son. Ia U.

37. THE CHAIR, a poem for my Jidu, by Walter S. Hamady, illustrated by Jack Beal. [4] leaves; $28 \mathrm{~cm}$; Sabon Antiqua; 75 copies on an experimental paper formed mostly of unbleached cotton linters; grey Fabriano wrappers."

38. ONE DAY TO SINTRA \& BACK, by Walter Hamady, with title-page illustration by Bartolameu Dos Santos. [6] leaves; $29 \times 14 \% \mathrm{~cm}$; Palatino; 100 copies on Shadwell paper; Fabriano wrappers."

39. FIRST POEMS, 1946-1954, by Galway Kinnell. [45] pp.; $211 \frac{1}{2} \times 14 \frac{1}{2}$ cm; Palatino in black, green, and blue; 150 copies on Shadwell paper; half-leather binding by Douglas Cockerell."

40. SPRING IS A SEASON AND NOTHING ELSE, by Rosemarie Waldrop. [17] pp.; 28\% x 16\% cm; Palatino; 111 copics on handmade paper, for subscribers only; wrappers."

41. A NEW YEAR'S GARLAND FOR MY STUDENTS/MIT 1969-70, by Denise Levertov. [19] pp; 213 x $15 \mathrm{~cm}$; Palatino; printed in 7 colors; 225 copies on 2 colors of Shadwell: the first 100 hors commerce, the remaining 125 press-numbered; handsewn into Fabriano wrappers of 2 colors. ${ }^{\circ}$

42. HOMAGE TO ADANA, by David Kherdian, illustrated with drawings by Robert Totten. [43] pp. including bastard title; $21 \%$ x $14 \% \mathrm{~cm}$; Palatino; 120 press-numbered copies on Shadwell "handmade for this book in particular"; hardbound in blue, with red leather hidden tips."

BULLETIN 7, a checklist of the prshbl prss Imtd, 1964-70. Broadside; $39 \times$ $29 \mathrm{~cm} ; 100$ or so copies on Shadwell."

BULLETIN 9, a checklist of th prshbl prss Imtd, 1964-70. Broadside; $38 \mathrm{x}$ $28 \mathrm{~cm}$; Palatino in blue and red; Shadwell."

COLD HOUSE, a poem, by Toby Olson. Broadside; $27 \times 14 \mathrm{~cm}$; Palatino; 80 copies on Shadwell, hors commerce, "printed as a Christmas surprise for the author."

FISHBONES (1944-1970), a poem for friends, by Walter the Hamady. Broadside; $37 \times 27 \mathrm{~cm}$; Sabon Antiqua in blue and red; 100 or so copies on special Shadwell "handmade from old shirts in the basement." 
ROOT RIVER, by David Kherdian, drawing by Bob Totten. Broadside; $28 \mathrm{x}$ $14 \mathrm{~cm} ; 110$ signed copies on Shadwell, all hors commerce."

1971

43. THE SHOES OF WANDERING, by Galway Kinnell, cover illustration by Walter S. Hamady. [15] pp.; $21 \times 14 \% \mathrm{~cm}$; Palatino in blue, red, and black; 100 copies, or less, on Shadwell, "the edition having been taken by subscription"; wrappers. Ia $U .^{*}$

44. THESE CHAIRS, by Walter Hamady, illustrated by Jack Beal. [26] pp.; $27 \times 18 \mathrm{~cm}$; Sabon Antiqua, designed by Jan Tschichold; 98 copies on paper made by hand by Edwin Amies \& Son in Maidstone, Kent; cloth and marbled paper boards by Norma Rubovits; pressmark by Sulayman Alamuddin from Beirut.

45. FIVE POEMS, by Khatchik Minasian, illustrated by John Wilde. [9] leaves; $21 \times 15 \mathrm{~cm}$; Palatino; 125 copies on Shadwell; handsewn in wrappers. Ia $U$."

46. GOING HOME AGAIN, by De Wayne Rail, with titlepage illustration by John Wilde. [31] pp.; $26 \%$ x $18 \mathrm{~cm}$; Palatino and Open Kapitalen; 125 copies on Shadwell; binding by Elizabeth Kner. (Author's first book.) ${ }^{\circ}$

47. AFTER THE FUNERAL OF ASSAM HAMADY, a narrative poem, by Sam Hamod, illustrated by Warrington Colescott. [6] leaves; 28 × 17 cm; Sabon Antiqua; 120 copies on Zotar/Shadwell ("We added the essence of thyme [\& nonna] to the pulp"); wrappers ("The flower filled cover paper was made as a cooperative effort of visiting proprietors of the Rob Run press and in their honor we call it Gieux Gieux")."

48. SELECTED POEMS, by J. V. Cunningham. [43] pp.; $24 \times 15 \mathrm{~cm}$; Palatino; 120 copies on a variation of Shadwell "made from worn bedsheets supplied by the poet's wife, blended with jute and new rag halfstuff"; bound in half-leather by Douglas Cockerell and Son. Ia U."

49. CHINESE FIGURES, second series, by W. S. Merwin. [11] pp.; $27 \mathrm{x}$ $11 \mathrm{~cm}$; Palatino; 120 copies on Shadwell; wrappers.

50. THE JOURNALS: BLUE MOUNDS ENTRIES, by Paul Blackburn, illustrated by Walter S. Hamady. [19] pp.; $29 \mathrm{~cm} ; 12$-point Palatino in blue, brown, and black; 125 copies on Shadwell papers, titlepage and colophon page embellished with a tracing spur; handbound by Elizabeth Kner and Birute Bulota in a thick Shadwell over boards. Ia $U .^{\circ}$

A FRAGMENT OF A NEVER ENDING STORY, by Walter Hamady, illustrated by Jack Beal. Broadside; $42 \times 18 \mathrm{~cm}$; Palatino; 50 (?) copies on grey handmade paper." 
POSTER for our exhibition at the Madison Art Center. Broadside; 38 x 28; Palatino in brown, red, blue, and purple; 50 (?) copies on Shadwell. ${ }^{\circ}$

SHOOTING PIGEONS, by Toby Olson, illustrated by Warrington Colescott. Broadside; $51 \times 31 \mathrm{~cm}$; Palatino; 50 copies on Shadwell."

A SHORT POEM, by Ruth Evans Brinker. Broadside; $11 \frac{1}{2} \times 20 \mathrm{~cm}$ (folded to $10 \mathrm{~cm}$ ); Palatino in black and blue; 50 copies on white paper.

THERE IS SUCH A PLACE, by Walter Hamady for Ed Gulesserian. Broadside; $28 / 2 \times 16 \%$ cm; Palatino in black, red, and 2 shades of blue; 50 or so copies on grey Shadwell."

51. POEMS FOR SELF THERAPY, by George Economou, with illustrations from John Wilde's sketchbook. [2] + 13 pp.; 18 x $18 \mathrm{~cm}$; Palatino, and Augustea filettata for display; 112 signed copies, or less, on variant colors of Shadwell; wrappers."

52. IN SIGHT OF BLUE MOUNDS, twenty poem pieces arranged by season, taken from a journal kept south of Blue Mounds and supplemented with a few pieces left over from the place in Springdale township, by Walter Hamady, illustrated by Ellen Lanyon. 25 loose leaves; $16 \times 20 \% \mathrm{~cm}$; Sabon in 5 colors; 125 press-numbered and unsigned copies on handmade Shadwell ("Each page is a different color and kind of Shadwell, making it a "paper sampler" "); loose sheets "held by a gold-stamped cloth-spined Swedish-marbled paper over boards slipping into a chamfered and lined box with matching cloth by Moroquain."

53. AN EVERYDAY CELEBRATION, by Mary Hamady. [11] pp.; 19 cm; Palatino; 55 copies on Shadwell; wrappers.

54. THE FAMOUS BLUE MOUNDS SCRAPBOOK, five poems, by Sam Hamod. [20] pp.; $9 \times 14 \mathrm{~cm}$; 10-point Palatino; 85 copies "on the scraps trimmed off the Shadwell we used on Sam's last book"; wrappers."

55. THE LIFE OF PARTS, or thanking you for the book on building birdfeeders, by Robert Vas Dias for Diane Wakoski, illustrated by Ellen Lanyon. [8] leaves; $23 \times 19 \% \mathrm{~cm}$; Sabon; 99 press-numbered and signed copies on several different Japanese handmade papers; "bound in rough wrappers individually decorated with our new rubber stampers."

ANOTHER FRAGMENT OF A NEVER ENDING STORY. VALENTINE'S DAY, CLEVELAND. Broadside; $26 \times 36 \mathrm{~cm}$; handset Sabon Antiqua; 78 copies on grey Shadwell." 
[CHECKLIST of the Prshbl Press, 1964-1972] Broadside; $47 \times 31 \mathrm{~cm}$; less than 200 copies on Shadwell."

HIS HANDS TALK IN A PRAISING VOICE, by Robert Vas Dias. Broadside; $43 \times 17 \mathrm{~cm}$; Sabon Antiqua; 59 copies on Shadwell. ${ }^{*}$

THE PURPLE FINCH SONG, by Diane Wakoski, illustrated. Broadside, 35 $x 17 \mathrm{~cm}$; Sabon; 97 copies on mauve Shadwell. (Included in The Wandering Tattler, item 67.)

1973

56. TWO STORIES, by Kenneth Bernard, the magic illustration by Ellen Lanyon. [14] leaves (including 1 illustration and 2 leaves of Japanese paper incorporating pressed leaves and butterfly); $24 \frac{11}{2} \times 16 \mathrm{~cm}$; text machine-set Centaur; 150 copies, or less, on Japanese hand-made Hosho; boards with embossed design on upper cover."

57. THE EGGPLANT SKIN PANTS AND POEMS, by Mary Laird [Hamady], illustrated with plates of 18 pen and ink drawings by the author. [46] pp.; $32 \times 24 \frac{1}{2} \mathrm{~cm}$; Palatino in black and red; 175 numbered copies, or less, on hand-made Japanese Hosho; hand bound in red cloth with blind-stamped illustration on upper cover.

58. SENECA JOURNAL I, a poem of Beavers, by Jerome Rothenberg. drawings by Marta Anderson. [10] leaves including bastard title; 27 cm; Sabon; 97 signed copies on various Japanese text papers; wrappers, with cover calligraphy by Bettye Lou Bennett."

59. THAT OTHER ALONE, poems, by William Stafford, illustrated by Ann Mikolowski. [22] pp.; $28 \mathrm{~cm}$; Sabon Antiqua; 120 signed and numbered copies on "Tawny Absorbent botanical drying paper"; handbound in pictorial boards by Mary Ellen Chapdu.

60. THANK YOU, CALL AGAIN, to all those who helped along the way, poems, by Ken Mikolowski, illustrated by Ann Mikolowski. [8] leaves, 3 folded twice; $23 \times 15 \mathrm{~cm}$; Palatino in 12 colors; 120 copies on several sizes of Shadwell handmade and Japanese papers; hand-sewn wrappers made from the Lake Saint Clair survey map."

61. INTERMINABLE GABBERJABBS, [by] Voltaire the Haemadeh, written and illustrated by Walter Hamady. Unpaged-about $28 \mathrm{pp}$. and folded map; up to $28 \times 16 \mathrm{~cm}$; Palatino; 120 copies on assorted Shadwell papers; Nideggen paper cover, with inner wrapper made from the Blue Mounds, Wisconsin, map of the Geological Survey. (Text consists of a poem, "For Ivan \& Oral.")

AND MORE PIGS, by Mary Hamady, illustrated by the author. Broadside; $37 \times 29 \mathrm{~cm}$; Palatino on Hosho." 
AVIAN MASTICATION CENTER, by Walter Hamady, illustrated by Mary Hamady. Broadside; $31 \times 48 \mathrm{~cm}$; Sabon; Hosho Special. ("Announcing the first show of the Hamady birdfeeder company." )

[CHECKLIST of the Perishable Press Limited, 1964-1973] Broadside; $51 \times$ $33 \mathrm{~cm}$.

GARDINER, MAINE, by Theodore Enslin. Broadside; 34 x $13 \mathrm{~cm}$; Sabon; 138 copies on Shadwell."

IF \& ONLY IF YOU ARE EXPECTED, PLEASE KNOCK; OTHERWISE LEAVE US ALONE, illustrated by Walter Hamady. Broadside; $31 \times 15 \%$ cm; Palatino; Hosho."

LIFE IN THE COUNTRY, by Mary Laird [Hamady], illustrated by the author. Broadside; $20 \times 38 \mathrm{~cm}$; Palatino on Hosho."

19 SAINT PATRICK'S DAY 73, titles in print \& in preparation. Broadside; $48 \times 16 \mathrm{~cm}$; in black and red. (The apostrophe in St. Patrick's is printed in green. $)^{*}$

THE OWL AND THE SNAKE, a fable, by Diane Wakoski, illustrated with a drawing by Ellen Lanyon. Folded broadside; $48 \%$ x $15 \% \mathrm{~cm}$; Palatino; 73 copies on Hosho, signed by the author."

THE PIGEONS, by William Heyen, illustrated by Mary Laird Hamady. Broadside; $33 \times 14 \mathrm{~cm}$; Sabon Antiqua; 158 copies on Shadwell signed by the author."

SEARCH FOR THE CAUSE OF EVIL, held for various purposes ecstatic journeys/a ritual for actors, a broadside play, by Rochelle Owens. Broadside; $51 \times 35 \% \mathrm{~cm}$; Palatino in blue and black; 55 copies on grey Shadwell."

\section{4}

62. HUNKERING IN WISCONSIN, another interminable gaggerblabb, by Walter Hamady, illustrated by Jack Beal. [11] pp.; $22 \mathrm{~cm}$; Herman Zapf's Palatino in red, grey-blue, and black; 125 copies on Shadwell; Nideggen paper cover."

63. FISHING, a single long poem, by Toby Olson, with an original mixed media print by William Weege DaBarba. [5] leaves of text; $37 \times 27 \mathrm{~cm}$; Sabon; 50 copies on Shadwell; bound to mixed media cloth cover, $83 \mathrm{x}$ $37 \mathrm{~cm}$, which folds to form three panels. (Imprint date of 1973.)

64. OPEN THE FLOWER, by Norman Russell [15] pp.; 19 × $16 \mathrm{~cm}$; Palatino; 125 copies on Shadwell ("Each page is shorter and alternates color with white so when open to center there are stripes across the bottom"); hand-sewn into Fabriano. 
65. PULSARS, three states of a single poem, by Harry Lewis, with an original silk screen print by Sam Gilliam. [16] pp., some folded; $28 \frac{1}{2}$ x 15\% cm; Palatino, Open Kapitalen, and Augustea in red, black, yellow, and blue; 150 copies on various papers; wrappers."

66. BOOK NO. 68, by Walter Hamady. [20] pp.; $13 \times 22 \mathrm{~cm} ; 34$ copies on different colored leaves of varying widths, some folded; wrappers ("The covers are scrawp hunks of navigational genuine maps"). Calligraphed printer's device by Sheikh Nassib Makarem. "This would be \#68 if we would count 2 pamphlets that were ads."

67. THE WANDERING TATTLER, poems, by Diane Wakoski, with eleven illustrations by Ellen Lanyon. [31] pp.; $33 \frac{1}{2} \times 18 \frac{1}{2} \mathrm{~cm}$; Palatino; 130 copies on Shadwell, 10 of which are pure white and slightly narrower; morocco-backed boards, in slipcase. Ia $U$.

68. REDSPEL, eleven American Indian adaptations, by Armand Schwerner, with three drawings by Roland Ginzel. [27] pp. of varying lengths; $35 \times 19 \% \mathrm{~cm}$; Palatino; 130 press-numbered copies on Nideggen and Frankfurt Cream ("only about 60 of these survived damage"); binding by Mary Ellen Chapdu."

69. THUMBNAILING THE HILEX, another (3) interminable gabberjabbs . . . by Voltaire (the) Hamady, illustrated by Jack Beal. [10] leaves; 38 x $20 \mathrm{~cm}$; Sabon; 125 copies on Frankfurt Cream; wrappers.

9.APRIL.1974, by Teddy M. Haggarty, illustration by Ellen Lanyon. Broadside; 38 x 17 cm; Sabon; Frankfurt Cream."

THE PERISHABLE PRESS LIMITED and THE SHADWELL PAPERMILL ESTD 1964, by Walter and Mary Hamady, books in stock as of our Sun's total eclipse, 19 June 1978. Broadside; $38 \times 16 \frac{1}{2} \mathrm{~cm}$; Palatino in red. black, grey, and brown; on Frankfurt."

\section{5}

70. THE INTERMINABLE GABBERJABB: VOLUME ONE (\&) NUMBER FOUR, by Walter Hamady, illustrated with photographs of the Hamadys by Gregory Conniff. [24] pp.; 16\% x $25 \% \mathrm{~cm}$; Palatino, "infiltrated by Augustea filettata and Weiss Series III"; 60 copies on assorted papers of varying sizes; wrappers.

71. A POEM TO CELEBRATE THE SPRING \& DIANE ROTHENBERG'S BIRTHDAY, IN FOUR PARTS, by Jerome Rothenberg, illustrated by Jody Shields. 8 leaves, 2 folded, with 4-leaf insert containing a folded collage; $15 \times 19 \% \mathrm{~cm}$; Palatino; 76 copies on various papers; wrappers. * 
A GREETING FOR THE NEW YEAR, by Jerome Rothenberg [et al.], drawing by Ellen Lanyon. Broadside; $38 \times 17 \mathrm{~cm}$ (folded to $10 \times 17 \mathrm{~cm}$ ); Sabon; 50 (?) copies on Nideggen.

LAURA EVANS HAMADY, PRINTER'S DEVIL, illustration by Jack Beal. Broadside; $27 \times 18 \% \mathrm{~cm}$; Sabon Antiqua in four colors; Plover Fineweave. (A birth announcement.) *

\section{6}

72. GUILLEM DE POITOU: HIS ELEVEN EXTANT POEMS, translated by Paul Blackburn, illustrated by Roland Ginzel. 31 pp.; $27 \mathrm{~cm}$; Sabon Antiqua from Stempel, handset by Mary Laird in 13 different colors; 165 press-numbered copies: 1-30 on white Shadwell for standing patrons of the press, 31-35 "are oddball copies that utilize variations and proofs," 36-165 on Frankfurt Cream as are the odd copies; hand binding by Kner and Anthony in Chicago. (A 12-page press-numbered and illustrated booklet of editor's notes is in a pocket inside the back cover.) AIGA Best Books, 1976. Ia $U$." $^{\circ}$

73. ACTS, a single poem printed in the season of revival \& reawakening as an act of friendship, by Joel Oppenheimer. [7] leaves; $18 \times 13 \frac{\mathrm{cm}}{\mathrm{r}}$; Palatino; 112 copies on vintage Shadwell; wrappers, with illustration blind-stamped on cover."

74. KICKING THE LEAVES, a poem in seven parts, by Donald Hall, with a colophonic boxwood engraving by Reynolds Stone. [10] leaves; $15 \mathrm{x}$ $18 \mathrm{~cm}$; Sabon; 125 press-numbered copies on Frankfurt; wrappers."

75. CHAPTER SEVEN from THE HOUR OF THE BELL, a novel concerning the Greek war of independence, by Harry Mark Petrakis, with an original signed drawing by Warrington Colescott. [19] leaves, folded titlepage; $24 \frac{1}{2} \mathrm{~cm}$; re-set monotype Spectrum in four colors; 150 pressnumbered copies, on alternating sheets of Frankfurt (white) and Frankfurt Cream mould-made papers; binding by Kner and Anthony, a different marbled paper for each binding. AIGA Best Books, 1976. ${ }^{\circ}$

76. THREE \& ONE, by Toby Olson, with two drawings by Mary Laird. [15] pp.; 13\% x $10 \mathrm{~cm}$; 6-point Sabon Antiqua from Stempel; 145 copies on Frankfurt and Frankfurt Cream (39 of which have "an egregious flaw"); wrappers."

77. TRIUMPH OF THE WILL, by Armand Schwerner, illustrated by Arthur Thrall. [12] leaves; 20/2 cm; Sabon; 150 press-numbered copies on alternating Frankfurt White and Cream papers; wrappers. Ia U."

COLD RAIN, 10 September 1972, journal poem, by Walter Hamady, drawing by Jack Beal. Broadside; $29 \times 46 \mathrm{~cm} ; 44$ copies." 
HAPPY BIRTHDAY LOVELY MARY, by Walter Hamady, illustrated by the author. Broadside; $30 \times 21 \mathrm{~cm}$; Sabon in five colored inks.

THESE DAYS, 29 February 1972, journal entry poem, by Walter Hamady, with drawing by Sondra Freckelton. Broadside; $32 \times 52 \mathrm{~cm}$; Palatino; approximately 50 copies."

78. WOWA'S FIRST BOOK, by Walter Hamady. [4] leaves; $5 \times 4 \mathrm{~cm}$; Sabon; 60 copies on Frankfurt Cream; wrappers. ("These little words are for Laura Evans Hamady, who is two years old January 1977.") "

79. SULPICIAE ELEGIDIA, elegiacs of Sulpicia, Gilbert Sorrentino versions. [19] pp.; $13 \times 17 \mathrm{~cm}$; Sabon Antiqua; 137 copies on handmade Perusia; sewn into Roma, handmade at the Fabriano mill."

80. DOCTOR MIRIAM, five poems, by her admiring husband, Toby Olson, and made more celebrational through the drawings of Sondra Freckelton and Jack Beal. $25 \times 17 \mathrm{~cm}$; Sabon; 144 press-numbered copies on Perusia; wrappers of moretto Roma."

81. FIGURES OF SPEAKING, by Michael Heller, with a collage by John Digby. [6] leaves (2 fold-outs); $24 \times 18 \mathrm{~cm}$; Sabon Antiqua from Stempel; 150 press-numbered copies on Eltham, from S. Barcham Green; Shadwell wrappers, with illustration reduced from the title page.

82. THE STORY OF JANE \& JOAN, by John Wilde, pictures with captions by the artist. 64 page surfaces, 27 printed; $31 \times 27 \mathrm{~cm} ; 25$ wordnumbered copies on foundry Sabon Umbria and Bodleian Cream; paste-paper binding by Bill Anthony, with blue oasis spine and corner tips, in Solander box. (The 12 etchings, on Umbria Cream in two greys, are numbered, dated, signed and individually tinted by the artist. $)^{\circ}$

83. LIT BY THE EARTH'S DARK BLOOD, by Jane Augustine. [19] pp.; $21 \times 13 \mathrm{~cm}$; Sabon and Augustea types; 150 press-numbered copies (Roman numerals) on Bodleian; sewn into Roma wrappers.

84. EPIPHANY 1978 \& HAPPY BIRTHDAY, from Laura Evans Hamady \& Friends, belated greetings for Christmas from The Perishable Press Limited, by Laura, Walter, and Mary Hamady with drawings by Laura. [6] leaves; $17 \times 14 \mathrm{~cm}$; Sabon and Typogravure; 80 copies; moretto wrappers." 
85. DOGGEREL EXCHANGE, by Frank Rubovits, including one drawing by Laura Evans Hamady. 20 x $13 \mathrm{~cm}$; Palatino and Initiales Typogravure; 125 copies on various handmade papers; wrappers. (Title page incorporates a birth announcement of twins Samantha Remington and Micah Laird Hamady, born June 28, 1978.)

86. LAST LIGHT, by August Derleth, illustrated by Frank Utpatel. Forthcoming.

87. GOAT COTTAGE DREAM POEMS, by Laurence T. Giles, with a special illustration by Warrington Colescott [Center page containing the illustration folds down to 4 pages of verse]. 20 pp.; I4 $\times 20 \mathrm{~cm}$; handset Sabon in black and grey beige; 119 press-numbered copies on Maidstone (Barcham Green Ltd.), Twinrocker (Brookstone, Indiana), and Shadwell ("made in the barn from the author's old clothing quickly torn by our neighbor, Alice Yeager, who has practically all of this township tearing rags!")."

88. TUFT BY PUFF, by William Stafford, illustrated by Elizabeth Coberly. Forthcoming.

[THREE ADVERTISEMENTS]: "The Story of Jane \& Joan." "Extrinsic Offerings in Spring, 1978 and Afterwards," and "1964-1977 eighty-three in fourteen." Broadside; $44 \times 45 \mathrm{~cm}$; in three colors; copies on Barcham Green cream paper."

TITLES RECENT AND TO COME, illustrated. Broadside; 37 x $13 \mathrm{~cm}$; printed in brown, blue, and red. ${ }^{*}$

UNIDENTICAL TWINS ARE BORN, illustration by Jack Beal. Broadside; $45 \times 24 \mathrm{~cm}$; printed in three colors on cream. (Birth announcement for Samantha Remington and Micah Laird Hamady, June 28, 1978. $)^{\circ}$ 

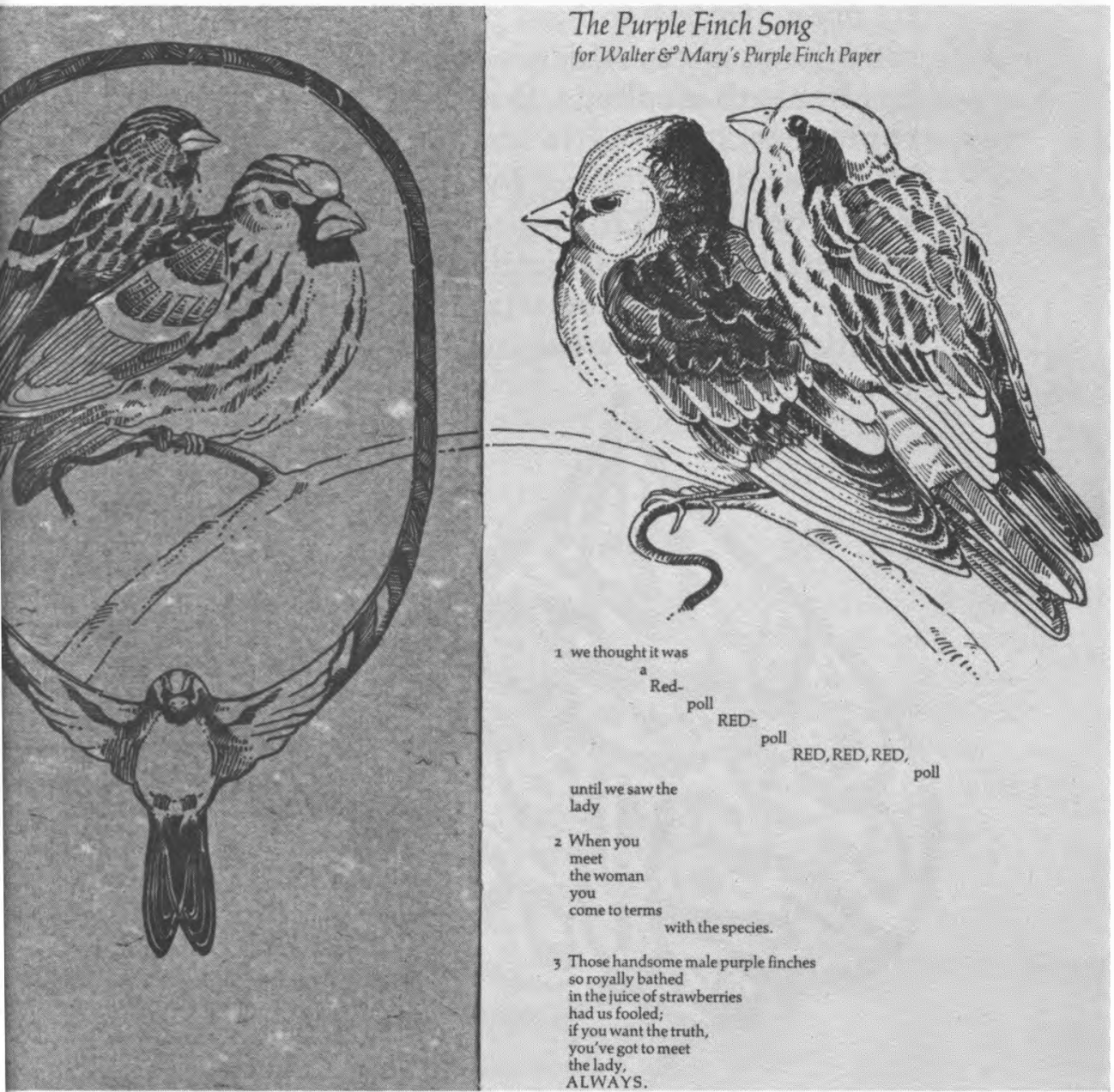

Opening from The Wandering Tattler, poems by Diane Wakoski, with illustrations by Ellen Lanyon (The Perishable Press Limited, 1974). 


\section{there are of the}

Spider Poems exactly two hundred and fifty copies hand printed, poem by poem, from hand-set palatino on nideggen papers which were folded by elizabeth stephens. there are fifty copies special, in little ways, signed by the author. binding by elizabeth kner. correspond to: walter hamady the perishable press limited po box three-0-one madison wisconsin. all printing known by the mark below

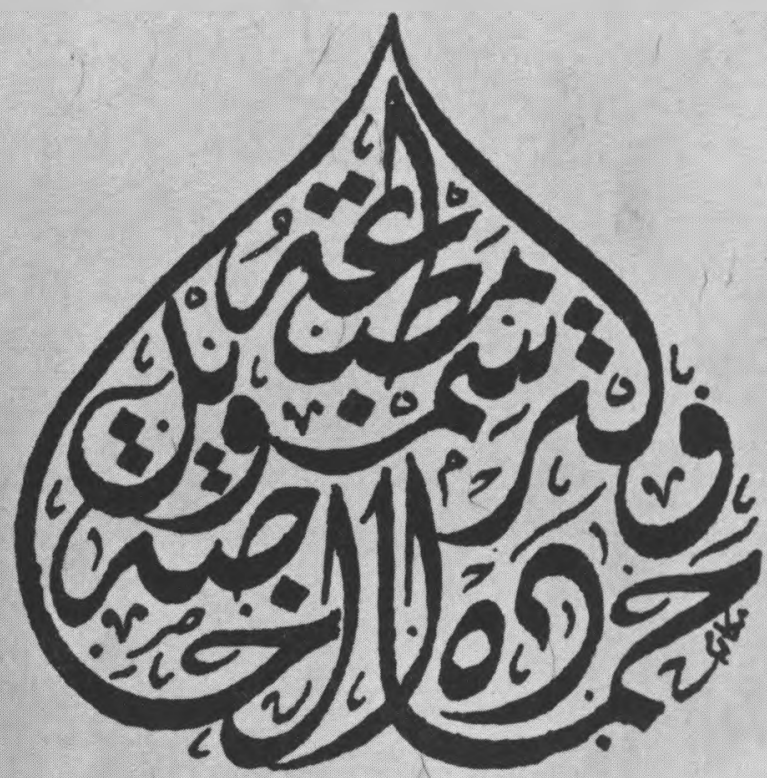

Colophon of Spider Poems by Walter Hall (The Perishable Press Limited, 1967), showing the arabesque mark of the press. 